\title{
The Strategy of Total Quality Management (TQM) in the Higher Education Library: Establishment of User Requirements for Information Requirements
}

\author{
Elva Rahmah, Marlini \\ Study Program of Information, Library, and Archive \\ Universitas Negeri Padang \\ elva@ffbs.unp.ac.id
}

\begin{abstract}
Total Quality Management (TQM) is an organizational culture that emphasizes on efforts to create quality and continuously improve quality through every activity of the organization. This research specifically aimed at: (1) knowing the leadership and staff's understanding of the TQM concept in Universitas Negeri Padang Library; (2) to get an idea of how managerial activities based on TQM are implemented to realize the quality of services in the Universitas Negeri Padang Library; (3) to know the role of leadership in encouraging the organization in implementing TQM principles in the Universitas Negeri Padang Library. This was a descriptive research method with qualitative approach. Data collection is performed through observation, interview and document analysis. The subjects in this study were the head, sub-head, library staff, library, events, facts, documents and various forms of efforts, programs or library activities. The object of this research was TQM system implemented in Universitas Negeri Padang Library. The results show that (1) the leadership and staff's understanding of the TQM concept influences performance because TQM requires the commitment and involvement of all members of the organization continuously; (2) managerial activities carried out based on TQM highly determined human resource competencies; (3) leadership roles in the Universitas Negeri Padang Library can be seen from (a) the leader develops the vision and sets the direction and strategy of the college library to produce the changes needed to achieve the vision, (b) the leader communicates the goals to be achieved through statements and actions anyone who may be required to give effect to the formation of a team that understands the vision and strategy of the college library, (c) the leader provides motivation for librarians and library staff, and (d) the leader must be able to create the desired change of the user and is very useful for library progress universities through the provision of new services that the reader wants and new approaches in working relationships that help college libraries compete.
\end{abstract}

Keywords-- total quality management, library services, user satisfaction

\section{INTRODUCTION}

The college library is a key component in assessing the success of educational programs in universities. It is management requires the handling of capable personnel, sufficient in quantity and quality. The librarian and librarians play a very important role in the success of a library. Librarians as the driving wheel of the library required high dedication and full dedication in charge of improving the role of the library. With the advancement of technology and the explosion of information the college library should improve its quality and sensitivity to advances that have to do with the development and improvement of service.

In the process of producing information on the college library products and services that suit the needs of user will win the competition. The process of information processing affects the process of procurement, processing and dissemination of information. On the other hand user became increasingly critical of the quality of goods and services. The college library is encouraged to continually improve quality. To be able to produce good service, in the process needed a management concept that can find a way out of problems that occur to the system both organically and individually, to improve performance and productivity. At this time, the need for information on the community is as important as basic needs. Decision-making requires information, so information becomes a very important commodity. The library in providing information should be oriented to the needs of the user. Libraries mark the circumstances of the external environment in which the reader is located, so as to provide services that suit the needs of the user. Patterns of people's lives are constantly changing, as are readers. The rapid development of information technology requires libraries to adjust to the circumstances so that the quality of services should be improved so that the library is not left by the user.

One way to improve the quality of library services is by improving the management system into a better management system. Quality is a philosophy and methodology that helps the agency to plan change and regulate in the face of external pressures. Service is an action that is closely related to human attitude and TQM is a management system that emphasizes on human empowerment and social aspects so that TQM is a system that needs to be implemented in the library. TQM can be achieved when all elements feel the need to get involved, therefore quality development will have a positive impact on librarians and benefit libraries.

Universitas Negeri Padang (UNP) Library is one of the academic pillars with the main task of providing library services and access to information center in order to improve the quality of learning, research and community service through the procurement of documents source of knowledge and information, manage, maintain and present information relevant to the needs of the curriculum, academic community and other community library service users. 
UNP Library is an effective and efficient system, which is very dependent on the successful implementation of work according to established standards. Working in a system, every element in the library should try and work together to make the system more efficient and productive. The phenomenon that occurs the number of collections is not proportional to the number of academicians, the lack of library staff, not all librarians are certified, no specialist subject matter, lack of IT staff for library IT development and lack of computer technicians, insufficient number of computer searches and unavailable space meet the needs of users such as discussion room, audio visual, interior of the building is less meet the needs and cleanliness is less awake.

The weaknesses of governance component are (1) administrative not yet maximizing total quality management, (2) short archives, well managed and (3) lack of system, control over. Solutions to the various problems that exist in the UNP Library, it is deemed necessary to learn how the application of TQM in the management of university libraries that will provide solutions university library managers to answer the challenges of the present and future. TQM can be used to develop the quality of library services responsive and able to respond to changes that occur in the field of libraries in order to give satisfaction to consumers.

Management problem is a major obstacle, the library managers in managing the library. Whereas many modern management principles that can be applied in the library. For example, the concept of four pillars of TQM can be applied to the library that is (1) satisfying the customers (costumers satisfactions), it is time library provide service that can satisfy user requirement; (2) respect for people, librarians and librarians are human beings who must be fully rewarded; (3) speak with facts, the library must recognize its capabilities clearly, the market potential served, and the development of the information; and (4) continuous improvement, the library continually improves and evaluates.

TQM with a concept that combines optimal strategies, systems and human resources, seems to be a concept that is expected to answer as a big problem-library problems. Because the principle of TQM is to express customer satisfaction, respect for everyone, fact-based management and continuous improvement (Lasa HS, 2005, p. 24). Libraries as service providers need to implement management to control the quality of services. This effort needs to involve all the library components with continuous coaching.

Assessment of libraries and librarians, no longer on quantity, but on quality / quality. Even various information technology devices have been used to improve the quality of service. As a service provider, it is not wrong if various disciplines are used to improve the quantity and quality of services one of them is the total quality management science or TQM. Implementation of integrated quality management is not an immediate approach or the result is obtained in an instant, but requires a systematic process (Mokoginta, 2012, p. 411).

User satisfaction is one of the goals of a library service. In addition, the library should always make changes continuously to achieve continuous quality ofthis library always provide an adequate collection, up-to-date information and adapt to technological developments. State University of Padang Library (UNP) is a critical component in assessing the success of educational programs in universities. Management requires the handling of capable and sufficient personnel in quantity and quality. The librarian and librarians play a very important role in the success of a library. Librarians as the driving wheel of the library required high dedication and full dedication in charge of improving the role of the library. With technological advances and information explosion, the library must raise its quality and sensitivity to advances that have to do with the development and improvement of services. In the condition of the high guidance of the high society of information, the main thing that must be prioritized by State University Library of Padang (UNP) is the satisfaction withits users.

The level of service user satisfaction in the UNP Library is determined by the performance of the librarian and the quality of the services provided. In essence understanding the satisfaction or dissatisfaction of users, is the difference between perceived expectations and performances. User satisfaction can be measured indirectly from whether or not they visit the information unit and utilize the services of UNP Library.

The UNP Library is in accordance with its duties and functions dealing with matters related to the procurement of library materials, library materials processing, and services. Each activity has a subsystem, have input, process and output and give the same contribution in achieving the goals and objectives that have been set. The results achieved are influenced by several factors, namely human resources, capital, material, managerial information and services served. Based on these conditions, a new management system is required by implementing TQM.

TQM is a modern management concept that seeks to respond appropriately to any changes that exist, driven by both external and internal forces. TQM is also a challenge to established traditional management theory (Tjiptono, 2001, p. 328)

The characteristics included in the TQM element are very suitable to be applied in libraries, as for these characteristics according to Tjiptono (2001, p. 239) are (1) focus on customers, both internal and external customers; (2) high obsession with quality; (3) the use of scientific approach in decision making and problem solving; (4) long-term commitment; (5) teamwork; (6) staff involvement and empowerment; (7) continuous process improvement; (8) the existence of botom-up education and training; (9) controlled freedom; and (10) the unity of purpose. Based on these conditions then in this paper will be discussed Strategy of application of TQM in the Library of Higher Education: Efforts to meet the needs of user information? 


\section{METHODS}

To view and get an overview of managerial activities based on TQM conducted by the leaders and library staff in realizing the quality of service. In accordance with the problems and objectives of the study, the type of research used descriptive research approaches used is a qualitative approach. Data collection is consisted of a depth observation, series of interview, and document analysis. Subjects in this study are leaders, sub-heads, library staff, users, events, facts, documents and various forms of efforts, programs or library activities. The object of this research is TQM system implemented in UNP Library.

\section{FINDING AND DISCUSSION}

\section{Understanding Leaders and Staff on TQM Concepts that Have Vision Focus on Users}

Understanding of leadership and staff of TQM concepts can be seen from the TQM concept implemented in UNP libraries that try to maximize the competitiveness of libraries through continuous improvement ofproducts, services, people, processes and library environments. UNP library leadership believes in the positive impact on implementation TQM in the library means that library leaders already have a picture of the impetus of the application of TQM in the library. As a result of this, the leaders of various library already have the the capital base of the to apply TQM.

Understanding of the concept of TQM alone is not enough to be able to implement the implementation of the concept of TQM in the UNP Library, therefore the understanding of the concept must be coupled with the commitment and belief that the application of TQM will have a positive impact for the UNP.TQM Library is the attitude and behavior based on satisfaction with work and work team or group. TQM wants total commitment from management as a library leader where this commitment should be disseminated to all librarians and in all levels or sections within the organization of the library.

Based on interviews with heads of libraries relating to the level of leadership confidence in TQM's positive impact on libraries, librarians believe that the application of TQM concepts in UNP libraries will benefit the library. Leaders play a role in the implementation of TQM programs ranging from setting goals to adequate time allocation. Commonly used organizational leadership is distinguished between four models of leadership styles: autocracy model, feudal model, egalitarian model, and anarchic model. The leadership models that fits perfectly with the TQM culture in the UNP Library is an egalitarian model, because in this model a leader gives employees the freedom to work. Employees communicate up and down within the UNP Library can even pass through other agencies. By observing the leadership's understanding of the TQM concept mentioned above, the authors argue that leaders understand the quality culture that can give meaning to the reality that builds commitment to quality improvement within the UNP Library.

The staff's understanding of the TQM concept seen from interviews with library staff can be summarized as follows.

Most of the interviews with UNP library staff have heard of the TQM concept, while few have never heard of the TQM concept. The library staff who have never heard of the TQM concept say that they are not following the development of the managerial field and the lack of information about TQM in the library.

\section{Managerial Based on TQM}

Managerial based on TQM conducted by the leadership of UNP Library cooperate human resources in the library environment. This can be seen from the positive behavior in work and the ability to maintain and develop the existence of the UNP Library. Based on interviews with library leaders related to managerial implementation based on TQM in UNP Library as follows.

Create a conducive working climate in the library environment. This is evident from the mutuality that is manifested in the form of good cooperation with respect and respect for opinions, creativity and initiatives to improve quality. In addition, the placement of library staff in accordance with the competencies and hobbies that are concerned.

Implementation of library managerial activities related to the TQM concept that must be done is benchmarking, continuous improvement, employee empowerment, team work, identify the customer, listening the customer, process analysis, and statistical proses control.

First, the concept of benchmarking by UNP Library is to conduct comparative studies with other libraries. The comparative study aims to look at the circumstances and model the processes and results achieved by other libraries to apply to the library itself so as not to be left behind by the advances made by the outside environment of the library. So this activity is very easy to implement, it only requires the willingness to see and compare the existing process with the process done in libraries that do the same process.

According to Gohle (in Clair, 1996, p. 59) states the concept of benchmarking aims to improve the performance of libraries by adopting the practice of other best libraries. So this activity is very easy to implement, it only requires the willingness to see and compare the existing process with the process done in libraries that do the same process. 
Second, continuous improvement, conducted in the library, is the presence or absence of work procedures that are guidelines for every activity undertaken in the library and within a certain period of time a review of the work procedure is performed. Based on interviews with library leaders related to the improvement in continuous procedures undertaken for the improvement in UNP Library as follows.

The UNP Library already has worked procedures, work procedures that already exist are written policies, and unwritten policies. Change of work policy of two factors that is internal factor that is change in organizational structure. This will impact on changes in some working procedures. External factors are usually a result of environmental influences overthe organization, such as the influence of the state of college.

A review of existing working procedures should be carried out continuously over a period of time. Based on interviews with library leaders, it is necessary to review the existing working procedures. All work procedures in the literature must be obeyed and a time the procedure may change in accordance with changes occurring within the organization. These changes can be seen from certain policy changes that cause work procedures to be reviewed, this aims to improve the quality of services through continuous improvement.

Third, the concept of staff empowerment in library activities can be seen from staff participation in key library activities such as in formulating staff policies and participation in decision-making processes, planning education programs and training for staff and providing greater staffing responsibilities.

Based on interviews with library staff as large library staff interviewed said they were included in policy formulation, involved in making decisions. This suggests that in formulating policies and in making decisions UNP Library staff has been involved. Relating to education and training for staff according to the library leadership is very important.

Providing greater responsibility to library staff has been done in the UNP Library. This concept shows that the leadership believes in his subconscious. Leaders' trusted in subordinates will lead to better morale for their subordinates. Subordinates will feel belonging, so that any creativity possessed by subordinates can be channeled into the work, so it can benefit the organization.

According to Tjiptono (1997, p. 108), the empowerment of staff manifests in an effort to give autonomy, authority and trust to each individual within an organization and encourage them to be creative in order to complete their tasks as best as possible. Through the empowerment of the staff, it is expected that the change will go to a better direction. By applying various managerial practices, organizational management can significantly reinforce subordinate beliefs in their own ability. With strong confidence the staff will be better able to do and succeed in performing various tasks.

The leadership of the UNP Library in the decision-making process begins with the collection of facts, data, and information based on the fact-oriented analysis of SWOT (Streight, Weakness, Opportunity, and Threat) and internal and external data within the library organization. Strategic planning with SWOT analysis approach as a form of evaluation towards change and improvement. Internal and external issues compiled by the leadership of UNP Library is reviewed from four aspects of human resources, systems, materials, and physical can be seen in the table below. 
Table 1. Summary of SWOT Analysis of Human Resources Components

\begin{tabular}{|c|c|c|c|c|}
\hline SWOT & Human Resources & System & Material & Physical \\
\hline Strength & $\begin{array}{l}\text { 1. Have librarians who number } \\
26 \text { people and have a library } \\
\text { of library certificate } \\
\text { 2. Assisted by administrative } \\
\text { staff consisting of archives, } \\
\text { computer institutions, and } \\
\text { administrative staff } \\
\text { 3. Has } 3 \text { librarians who have } \\
\text { been certified } \\
\text { 4. Have an accomplished } \\
\text { librarian an skilled and } \\
\text { 5. Led by a in the } \\
\text { experienced person in } \\
\text { library field } \\
\text { 6. Service users who meet } \\
\text { service standards }\end{array}$ & $\begin{array}{l}\text { 1. Leaders have a high } \\
\text { commitment to } \\
\text { library } \\
\text { development } \\
\text { 2. There is a clear } \\
\text { organizational } \\
\text { structure and job } \\
\text { description }\end{array}$ & $\begin{array}{l}\text { 1. Availability of library } \\
\text { collections in printed and } \\
\text { electronic form from various } \\
\text { disciplines of science } \\
\text { 2. Various collections are } \\
\text { provided } \\
\text { 3. Up to date collection } \\
\text { 4. Availability of complete } \\
\text { collection a popular } \\
\text { 5. Availability of agazine collections and } \\
\text { magazine } \\
\text { scientific magazines }\end{array}$ & $\begin{array}{l}\text { 1. Location of strategic } \\
\text { library building } \\
\text { 2. It has a spacious } \\
\text { building and } 5 \text { floors } \\
\text { 3. The color of the } \\
\text { library paint is } \\
\text { interesting orange } \\
\text { color }\end{array}$ \\
\hline Weakness & $\begin{array}{l}\text { 1. Lack of number of library } \\
\text { staff } \\
\text { 2. Not all librarians are certified } \\
\text { 3. There is no specialist subject } \\
\text { 4. Lack of power information } \\
\text { technology to the } \\
\text { development of information } \\
\text { technology library } \\
\text { 5. Lack of computer technicians }\end{array}$ & $\begin{array}{l}\text { 1. Administration has } \\
\text { not been fully } \\
\text { implemented TQM } \\
\text { 2. The archive has not } \\
\text { been properly } \\
\text { managed } \\
\text { 3. Lack of a system of } \\
\text { control over the } \\
\text { mailings }\end{array}$ & $\begin{array}{l}\text { 1. The number of collections is } \\
\text { not proportional to the } \\
\text { number of civitas academica } \\
\text { 2. Number of collections that } \\
\text { have been damaged }\end{array}$ & $\begin{array}{l}\text { 1. Interior of buildings } \\
\text { that do not meet the } \\
\text { needs } \\
\text { 2. Lack of building } \\
\text { maintenance } \\
\text { 3. Toilets that have not } \\
\text { met the standard } \\
\text { 4. Cleanliness is less } \\
\text { awake }\end{array}$ \\
\hline $\begin{array}{l}\text { Opportuniti } \\
\text { es }\end{array}$ & $\begin{array}{l}\text { 1. These are the people whose } \\
\text { homes exacerbating an } \\
\text { already dire in full and further } \\
\text { increase learning } \\
\text { opportunities insight into the } \\
\text { subject of as joined the } \\
\text { training, a seminar with a } \\
\text { continuing their studies } \\
\text { 2. Conduct training for librarians } \\
\text { 3. The existence of regular } \\
\text { training from National Library } \\
\text { of Indonesia } \\
\text { 4. Conduct comparative studies } \\
\text { to more advanced libraries } \\
\text { 5. Librarian certification }\end{array}$ & $\begin{array}{l}\text { 1. Divide TQM in the } \\
\text { management of } \\
\text { accredited libraries } \\
\text { 2. Promotion of office } \\
\text { 3. The existence of } \\
\text { remuneration } \\
\text { 4. Increase in job } \\
\text { allowance } \\
\text { 5. The existence of } \\
\text { librarian } \\
\text { certification } \\
\text { 6. Existence of } \\
\text { overtime }\end{array}$ & $\begin{array}{l}\text { 1. Availability of electronic } \\
\text { collections (e-journal and e- } \\
\text { book) that open access } \\
\text { 2. Trial access from the } \\
\text { publisher } \\
\text { 3. Inter Library Loan } \\
\text { (cooperation } \\
\text { universities) } \\
\text { 4. Availability of collections } \\
\text { published abroad }\end{array}$ & $\begin{array}{l}\text { 1. Fix the building } \\
\text { 2. Create space barriers }\end{array}$ \\
\hline Threat & $\begin{array}{l}\text { 1. Advanced technology } \\
\text { profession the librarian will } \\
\text { replaced by another profession } \\
\text { 2. The development of library } \\
\text { science and information } \\
\text { technology very quickly } \\
\text { 3. The less number of library } \\
\text { staff, because the work has } \\
\text { been replaced by many } \\
\text { technologies. }\end{array}$ & $\begin{array}{l}\text { Rules or policies that } \\
\text { change at any time }\end{array}$ & $\begin{array}{l}\text { 1. Limited library space } \\
\text { 2. Vandalism performed by the } \\
\text { user } \\
\text { 3. Damage caused by the } \\
\text { accidental air of the library } \\
\text { near the coast } \\
\text { 4. The library has not been } \\
\text { given the authority to } \\
\text { procure the collection so that } \\
\text { many collections are held } \\
\text { not in accordance with the } \\
\text { request } \\
\text { 5. Lack of reading interest in } \\
\text { foreign-language collections }\end{array}$ & $\begin{array}{l}\text { 1. The occurrence of } \\
\text { natural disasters } \\
\text { 2. Termites } \\
\text { 3. Collapse of the } \\
\text { library } \\
\text { 4. Fire event }\end{array}$ \\
\hline
\end{tabular}

Fourth, working with a work team means working with one or more members of a group. Working with teams means there is interaction between group members working together for a defined purpose. When working with a team, responsibility for the work is the responsibility of all team members. The decision taken is the team's decision. Working and making decisions with the team, it seems to be something that has been done in the UNP Library and this is one of the important TQM concepts. Working with teams is an effective approach that has been felt by many organizations including the UNP Library. 
The provision of information in the library can work well if all components that have certain skills form a team in producing information in the library. With the existence of several people who are experts in their respective fields then the work can be completed more effectively. Leaders and all librarians in achieving the goals are a group of mutual selfinvolvement, mutual explanation, mutual motivation to move forward and organize organizational development commitments even though there are still a few staffs that does support it, but this is not an obstacle in implement program development.

In making the decision of the library leaders hold the principle of joint decisions namely the decision of the team with the functional who has a position as head of affairs. The library leader involves all human resources libraries to share responsibilities according to their core abilities. The goal is that all decisions are presented through deliberation.

Fifth, Identificationuser are the targets the end of a product produced to can provide relevant information we need to examined assemble usersUNP library. For Library UNP user is very important because one component of the library is a library service user. In other words, no library libraries have no meaning.

Sixth, listen to the opinions of the user can be done through the process of system evaluation. System evaluation is an effective way to know the weakness of a system that has been running in the library. Gathering the views of the user to the system that runs from the bad service provided by the library staff, the speed of staff in serving the users, and the satisfaction of the users of the library collection. Listening is a very important managerial aspect. By listening to the opinion of the librarian, the librarian will know where the weaknesses of the system and will quickly find a solution to the existing constraints.

As an effort UNP Library in capturing any opinions of librarians related to library services. Opinion's opinion is positive and there is also a negative, it is a feedback about the satisfaction of the users and the quality of management.

Seventh, the process analysis activities carried out on the system aims to maintain the system from error. Libraries carry out process analysis of existing processes, so whether the process goes well or not. Analysis of the process carried out in the library of library information systems, both libraries that still adhere to manual systems and systems that are already automated. If the process is periodically analyzed, it will avoid fatal errors or errors that arise can be attempted as small as possible. The TQM concept emphasizes on continuous process improvement. This continuous improvement of the process must go through process analysis, which ultimately leads to improved product and service quality.

Eighth, process control is statistically meant to describe the library situation at any given time and to monitor any errors or deficiencies. Recording of facilities and infrastructure is carried out continuously, reporting physical evidence of performance results of functional librarians, visitor statistics, lending statistics, user statistics and library user requests are accurate records for decision-making materials.

Implementing TQM Principles

In order to realize a quality library and in line with UNP vision, the library has a vision that supports UNP's vision of "becoming a prime information center, modern, up to date, and as a primary means of academic transformation of science, technology and art on the basis of faith and taqwa to God Almighty ".

This vision is formulated into the library mission to be implemented in accordance with the goals and objectives to be achieved. Mission a way library does to realize a vision. The mission of UNP Library is to (1) provide, administer, maintain, and reposition the relevant literature information documents according to the needs of the UNP curriculum; (2) provide library services and access to literature information centers in order to improve the quality of learning, research and community service (3) to provide and facilitate the UNP academic community for access to a global scientific information center in accordance with the development of information technology science, and (4) to capture and deposit literary works of academicians and alumni to become reference materials or references internal UNP.

To achieve these objectives, realistic and measurable objectives should be set based on clear and decisive policies. These targets are outlined in the form of integrated programs so as to produce activities that are of benefit to the UNP academic community. All of these activities will reflect the performance of the library within a certain period of time. The results of library performance can be known after evaluated based on existing indicators.

To improve the quality of library services requires a touch of creativity from everyone involved in the library. Not just leaders who are required to think creatively, but everyone in the organization must be grown creativity. Leaders must be able to accommodate the creative thinking of each library staff, which may be different from the angle of the field it has.

Leaders in a library prosecuted proactively always make efforts to improve the productivity of librarians to be more reliable, innovative and professional in working to meet the goals of the library through organizational communication. It aims to achieve productivity. Therefore the leader must be able to motivate his subordinates.

The most difficult challenge for a leader is how to motivate members of the organization. Every organization leader would crave a situation where all members of the organization he leads have a high level of passion and productivity.

Conditions of an organization, both government and private organizations, if the psychological condition of employees less supports, it will affect the effectiveness of organizational activities. Moreover, if the condition is derived from employee motivation. It will affect the success of achieving the goals and objectives that have been set. In an organization, although the job description has been set in the main duties and functions of the organization but not yet 
sufficient. If the employee is less enthusiastic, the employee's performance becomes less good, so the productivity decreases which in turn the execution of the task is not achieved as planned.

With regard to employee productivity, there are some influences such as motivation, education, training, skills, general knowledge, technical knowledge, work experience, cultural background, organizational climate, lighting, air temperature, salary / wages and others. Several productivity factors are mentioned, motivation is one factor that is very important in order to encourage employee productivity. Each employee work hard and enthusiastic because of the motivation. The capabilities and skills possessed by the employees are meaningless if they do not want to work hard and have not achieved the effectiveness of tasks as a result of lack of morale and willingness of employees who will disappoint the various parties.

To implement the TQM principles in the UNP Library needs to pay attention to teamwork, stakeholder engagement, and user involvement. According to Zahroh (2014, p. 56), strategies to improve team performance in achieving the goals to be achieved in educational institutions are interdependence, the existence of extension of tasks, alignment, use of common language, the presence of trust / respect, the leadership, the skills in problem solving, skills in dealing with confrontation / conflict, assessment / action, and appreciation.

\section{CONCLUSION AND RECOMMENDATION}

From the results of research conducted related to strategy implementation of TQM in UNP Library can be concluded as follows: First, the leadership and staff's understanding of the TQM concept influences performance because TQM requires the commitment and involvement of all members of the organization on an ongoing basis. Second, managerial activities conducted under TQM are highly determined human resource competencies. Third, the leadership role in UNP Library can be seen from (a) the leader develops the vision and sets the direction and strategy of the college library to produce the changes needed to achieve the vision; (b) the leader communicates the goals to be achieved through statements and actions to anyone who may be required to give effect to the formation of a team that understands the vision and strategy of a college library; (c) leaders provide motivation for librarians and library staff; and (d) the leader must be able to create the desired change of the user and is very useful for the advancement of the college library through the provision of new services desired by the user and a new approach in working relationships that help the college libraries compete. Thus, to improve the performance of UNP libraries it should adopt TQM concepts and implement them in the activities of UNP Library and library leaders as drivers of commitment on quality should set an example.

\section{References}

Maleong, L. J. (2004). Metodologi penelitian kualitatif. Bandung: PT Remaja Rosdakarya.

Mokoginta, H. E. L. (2012). "Implementasi Manajemen Mutu Terpadu Dalam Peningkatan Kualitas Pendidikan Tinggi." APTEKINDO, 6(1).

Pasaribu, H. (2010). "Pengaruh Komitmen, Persepsi dan Penerapan Pilar Dasar Total Quality Management terhadap Kinerja Manajerial (Survei pada BUMN Manufaktur di Indonesia).” Jurnal Akuntansi dan Keuangan 11(2).

Rivai, V \& D, M. (2012). Kepemimpinan dan perilaku organisasi. Jakarta: Rajawali Pers.

Tjiptono F. (2003).Total quality management. Yogyakarta: Andi.

Tjiptono, F. (2001). Total quality management. Yogyakarta: Andi.

Tjiptono, F. (1997). Prinsip-prinsip total quality service. Yogyakarta: Andi.

Zahroh, A. (2014). Total quality management: teori\&aplikasi manajemen untuk mendongkrak mutu pendidikan. Yogyakarta: Ar-Ruzz Media.

Zjulla, N. (2015). "Implementasi Total Quality Management sebagai Upaya Meningkatkan Kualitas Pelayanan di Perpustakaan Perguruan Tinggi." Libraria: Jurnal Perpustakaan, 3 (1), p. 93-109. 